\title{
Pencirian Sifat Akuifer dalam Batuan Granit di Selangor
}

(Characterization of Aquifer Properties in Granite in Selangor)

\author{
HAMIZAH MOHAMAD \& NORSYAFINA ROSLAN*
}

\section{ABSTRAK}

Di Selangor, sumber air bawah tanah dijadikan sumber bekalan air alternatif bukan sahaja oleh pelbagai jenis industri malah untuk kegiatan kuari. Kebanyakan telaga abstraksi ini adalah di dalam akuifer batuan teretak sama ada di dalam batuan metasedimen ataupun batuan granit. Memandangkan terdapat pertambahan penggunaan air bawah tanah dari semasa ke semasa, adalah penting untuk mengetahui cirian akuifer batuan teretak terutamanya dalam batuan granit ini. Oleh itu, satu kajian telah dijalankan untuk mencirikan sifat akuifer dalam batuan granit di Selangor. Kaedah kajian melibatkan cerapan lapangan di kuari IJM Sungai Buloh dan analisis data lubang gerudi, ujian pengepaman dan analisis kimia air bagi semua telaga dalam batuan granit di Selangor. Hasil kajian menunjukkan bahawa kawasan kajian terdiri daripada akuifer retak terkekang hingga separa terkekang. Log telaga merekodkan kehadiran lapisan tanah baki yang terdiri daripada lempung berpasir hingga lempung keras dengan ketebalan sehingga $50 \mathrm{~m}$. Lapisan bawah pula dilapisi oleh batuan granit teretak yang bertindak sebagai lapisan pengandung air. Kekar ditemui pada kedalaman 18 hingga $145 \mathrm{~m}$. Analisis lineamen menunjukkan korelasi positif dengan analisis ketakselanjaran di lapangan; berarah timur laut - barat daya dan barat laut - tenggara, selaras dengan zon sesar Kuala Lumpur dan Bukit Tinggi. Nilai keterusan berjulat 2.6 hingga $36.1 \mathrm{~m}^{2} /$ hari manakala julat kekonduksian hidraulik adalah 0.06 hingga $4.6 \mathrm{~m} / \mathrm{hari}$. Kadar luahan telaga adalah $<10 \mathrm{~m}^{3} / \mathrm{jam}$. Jumlah pepejal terlarutnya adalah rendah $(<372 \mathrm{mg} / \mathrm{L})$. Kehadiran retakan di dalam batuan granit akuifer ini telah membantu meningkatkan keupayaannya sebagai akuifer. Analisis kimia menunjukkan ada telaga yang berpotensi mengalami pencemaran.

Kata kunci: Akuifer bandaran; batuan teretak; granit

\section{ABSTRACT}

In Selangor, groundwater is used as an alternative water source in manufacturing industry and also for quarry activity. These abstraction wells are located in either fractured metasediment or granitic rock aquifer. It is important to understand the characteristic of fractured rock aquifer especially in granite due to its increasing demands. Therefore, this study aimed on characterizing the aquifer behavior in fractured granite in Selangor. The study methods used include detailed mapping at IJM Quarry at Sungai Buloh and analysis of well logs, pumping test analysis and well water chemistry for wells in granite in Selangor. The results showed that the aquifer type is confined to semi-confined aquifer. Well log indicates the presence of residual soil layers comprises of sandy clay to hard clay with thickness up to $50 \mathrm{~m}$. The bottom layer is underlained by fractured granite which acts as water bearing layer. The fractures are observed at 18.27 to $144.9 \mathrm{~m}$ depth. Lineament analysis in study area shows a positive correlation with discontinuity analysis in the field in the direction of northeast-southwest and northwest-southeast, which is in line with Kuala Lumpur and Bukit Tinggi fault zone. Transmissivity values range from 2.6 to $36.1 \mathrm{~m}^{2} /$ day while hydraulic conductivity values from 0.06 to $4.6 \mathrm{~m} /$ day. Well discharge rate is $<10 \mathrm{~m}^{3} / \mathrm{h}$. Total dissolved solids values are low $(<372 \mathrm{mg} / \mathrm{L})$. The fractures in granite have increased its capability as an aquifer. Chemistry analysis showed that there are possibility of few localized being polluted.

Keywords: Fractured rock; granite; urban aquifer

\section{PENGENALAN}

Aliran air bawah tanah dalam batuan granit teretak sebahagian besarnya adalah bergantung pada sifat retakan seperti sesar dan kekar (Singhal \& Gupta 1999). Dalam jasad batuan keras seperti granit, ruang liang antara butiran adalah sangat kecil dan hampir semua aliran air bawah tanah adalah melalui retakan di dalam batuan (Saim 1991) yang dikenali sebagai keliangan sekunder (Henriksen \&
Braathen 2006). Memandangkan penggunaan air bawah tanah semakin bertambah dari semasa ke semasa, adalah penting untuk mengetahui cirian akuifer batuan teretak terutamanya batuan granit bagi memudahkan kerja-kerja pemantauan kualiti dan kuantiti air bawah tanah pada masa akan datang. Kawasan kajian melibatkan telaga dalam batuan granit di kawasan kilang dan kuari di Sungai Buloh, Cheras, Kajang, Semenyih dan Beranang, Selangor. 


\section{BAHAN DAN KAEDAH}

Kaedah kajian melibatkan dua sumber data iaitu data primer dan data sekunder. Data primer diperoleh daripada kerja lapangan yang dijalankan di kawasan kuari IJM Sungai Buloh merangkumi pemetaan geologi, survei ketakselanjaran, pemantauan paras air telaga serta pengukuran parameter in-situ. Selain itu, analisis lineamen dijalankan dengan membuat surihan lineamen ke atas peta saliran Selangor. Data sekunder pula diperoleh daripada Jabatan Mineral dan Geosains (JMG) yang merangkumi data log telaga, data ujian pengepaman, data paras air serta data analisis kimia air telaga dalam batuan granit di Selangor.

Cerapan geologi telah dijalankan di kuari IJM Sungai Buloh untuk mengenal pasti jenis batuan, mineral pembentuk batuan, struktur geologi serta topografi di kawasan kajian. Cerapan lapangan ini kemudiannya dibandingkan dengan data log litologi telaga yang diperoleh. Log litologi subpermukaan setiap kawasan dikorelasikan bagi menghasilkan sebuah model konsep geologi bagi setiap kawasan.

Analisis lineamen rantau dijalankan dengan membuat surihan ke atas lineamen jenis negatif seperti lembah dan sungai pada peta saliran Selangor. Lineamen jenis negatif yang disurih dapat menggambarkan struktur lineamen rantau di kawasan kajian. Nilai jurus setiap garis lineamen yang disurih telah direkodkan dan arah utama set lineamen rantau kemudiannya ditentukan menggunakan gambarajah mawar. Hasil analisis ini seterusnya dikorelasikan dengan analisis ketakselanjaran di lapangan bagi melihat sekiranya terdapat perkaitan di antara arah utama set retakan di kawasan kajian dan arah lineamen rantau.

Survei ketakselanjaran pada cerun telah dijalankan di kuari IJM Sungai Buloh berdasarkan parameter yang dicadangkan oleh Brown (1981). Parameter seperti jenis, orientasi dan panjang ketakselanjaran, jarak pisahan, bukaan, kekasaran permukaan, bahan pengisi dan kehadiran air pada singkapan telah direkodkan. Survei ini dijalankan menggunakan kaedah garis imbasan pada tiga buah singkapan cerun yang berbeza (cerun A, B dan C) dengan 344 bacaan ketakselanjaran telah direkodkan. Garis imbasan sepanjang $10 \mathrm{~m}$ ini dilakukan secara rawak bagi mewakili setiap singkapan batuan. Data yang diperoleh diplot menggunakan perisian GeoRose.

Analisis ujian pengepaman melibatkan ujian pengepaman di kuari IJM Sungai Buloh dan analisis data ujian pengepaman yang diperoleh daripada Jabatan Mineral dan Geosains (JMG). Sebanyak 7.5 L air telah dibuang dan perubahan paras air dengan masa di telaga tersebut diukur. Kaedah ini dapat menentukan nilai keterusan dan kekonduksian hidraulik akuifer di kawasan tersebut iaitu, analisis data ujian pengepaman pula telah dilakukan ke atas 16 buah telaga. Parameter hidraulik diperoleh hasil analisis data ujian pengepaman menggunakan perisian AquiferWin32. Terdapat tiga jenis ujian pengepaman yang dijalankan pada setiap telaga iaitu ujian surutan bertingkat, ujian luahan tetap dan ujian pemulihan.
Seterusnya, analisis data kimia air dijalankan menggunakan data kimia air yang dibekalkan oleh pihak kuari IJM Sungai Buloh dan data analisis kimia makmal bagi sampel air bawah tanah daripada 16 buah telaga dalam batuan granit di Selangor. Manakala pengukuran in-situ melibatkan parameter fizikokimia seperti $\mathrm{pH}$, suhu, kekonduksian (EC), oksigen terlarut (DO) dan jumlah pepejal terlarut (TDS) juga dijalankan di telaga pemantauan di kuari IJM Sungai Buloh menggunakan alat multi parameter model YSI 556 MPS.

Pergerakan aliran air bawah tanah dalam keadaan statik ditentukan melalui penghasilan peta kontur paras air bawah tanah iaitu dengan menggunakan maklumat hulu air bawah tanah (hydraulic head) bagi setiap telaga.

\section{KEPUTUSAN DAN PERBINCANGAN}

\section{GEOLOGI KAWASAN KAJIAN}

Rajah 1 menunjukkan peta geologi kawasan kajian. Kawasan kajian secara umumnya terdiri daripada batuan granit yang merupakan sebahagian daripada Granit Banjaran Titiwangsa. Batolit granit ini telah merejah batuan Formasi Bukit Kenny pada usia Trias (Cobbing et al. 1986). Formasi Bukit Kenny dicirikan oleh jujukan selanglapis syal, batu lodak dan batu pasir yang berusia Karbon hingga Perm.

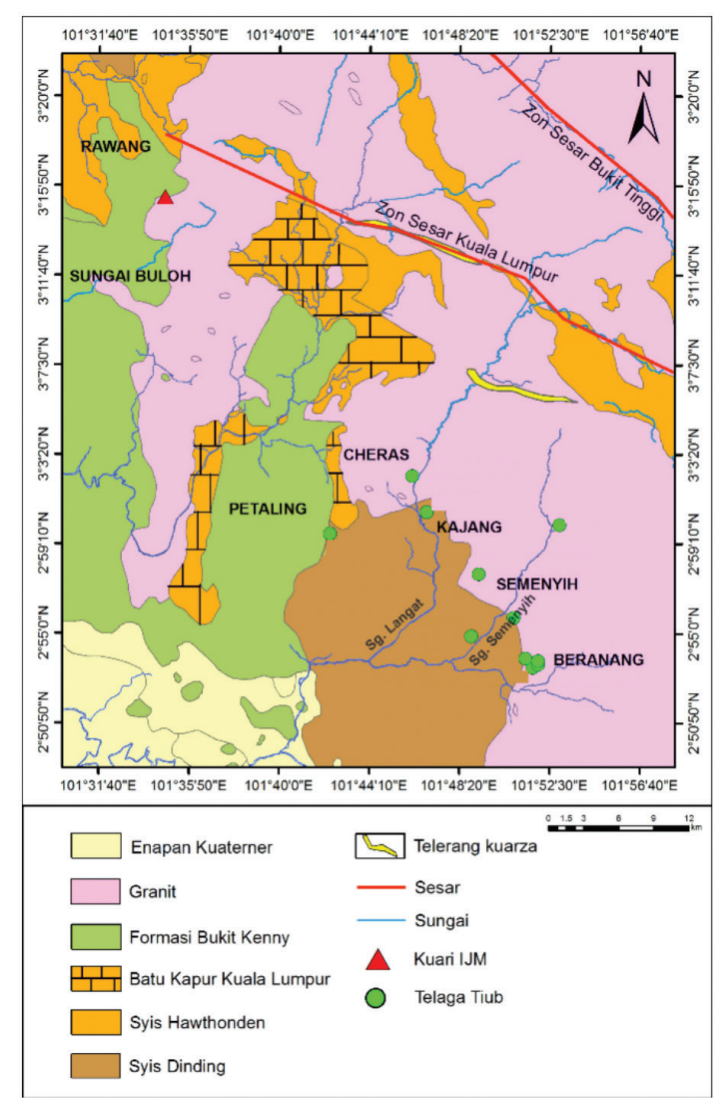

RAJAH 1. Peta geologi kawasan kajian

(Diubah suai daripada Jabatan Mineral dan Geosains 2014) 


\section{CERAPAN GEOLOGI LAPANGAN DAN ANALISIS LOG TELAGA}

Berdasarkan cerapan geologi lapangan di kuari IJM Sungai Buloh dan analisis terhadap data log telaga di kawasan kajian, jenis akuifer di kawasan kajian adalah jenis terkekang. Jenis akuifer ini wujud apabila air bawah tanah disempadani oleh lapisan pengekang di bahagian atas dan akuifer di bahagian bawah. Lapisan lempung berpasir dan pasir berlodak, lempung hingga pasir, serta lempung keras masing-masing di kawasan Beranang (Rajah 2(a)), Semenyih (Rajah 2(b)) dan Kajang (Rajah 2(c)) bertindak sebagai lapisan terkekang yang mempunyai ketelapan yang rendah dengan nilai kekonduksian hidraulik, $\mathrm{K}$ berjulat daripada $10^{-8}-10^{-2} \mathrm{~m} /$ hari (Brassington 1998). Julat ketebalan lapisan ini adalah daripada 8.7 hingga 50 m daripada permukaan.

Lapisan batuan granit teretak di kawasan ini pula bertindak sebagai akuifer. Ketebalan lapisan batuan ini menjangkau sehingga $152 \mathrm{~m}$. Kehadiran retakan dalam batuan adalah pada kedalaman 19 hingga $145 \mathrm{~m}$. Tiada kehadiran telerang kuarza yang dicatatkan. Batuan granit segar mempunyai ketelapan, $\mathrm{K}$ yang sangat rendah iaitu
$3 \times 10^{-4} \mathrm{~m} /$ hari dan nilai $\mathrm{K}$ boleh meningkat sehingga 0.03 $\mathrm{m} /$ hari dengan kehadiran retakan dalam granit (Brassington 1998).

\section{ANALISIS KETAKSELANJARAN}

Sebanyak 344 bacaan set kekar yang dapat ditemui pada singkapan muka cerun di kuari IJM Sungai Buloh. Bagi cerun A, arah utama set kekar di cerun ini adalah timur laut - barat daya manakala cerun B menunjukkan dua arah utama iaitu pada arah timur laut - barat daya dan barat laut - tenggara. Arah utama set kekar pada cerun C pula adalah barat laut - tenggara.

\section{ANALISIS LINEAMEN RANTAU}

Terdapat dua arah set utama lineamen rantau di kawasan kajian iaitu berarah timur laut - barat daya dan barat laut - tenggara (Rajah 3). Arah utama lineamen yang dominan tertumpu pada arah barat laut - tenggara iaitu pada sekitar $\mathrm{U} 135^{\circ} \mathrm{T}-\mathrm{U} 315^{\circ} \mathrm{T}$. Hasil analisis ketakselanjaran dan lineamen rantau menunjukkan trend pada arah yang sama iaitu timur laut - barat daya dan barat laut - tenggara. Ia

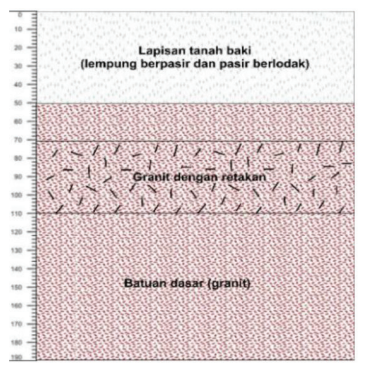

(a)

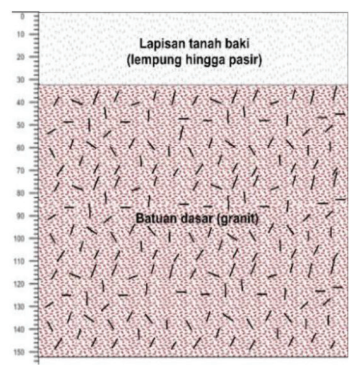

(b)

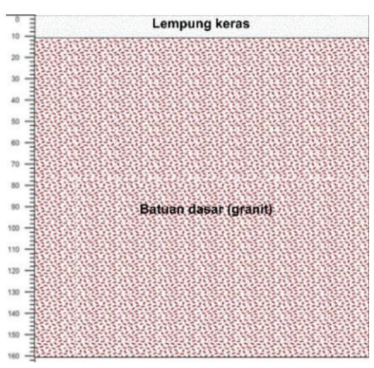

(c)

RAJAH 2. Model konsep geologi bagi kawasan Beranang (a), Semenyih (b) dan Kajang (c)

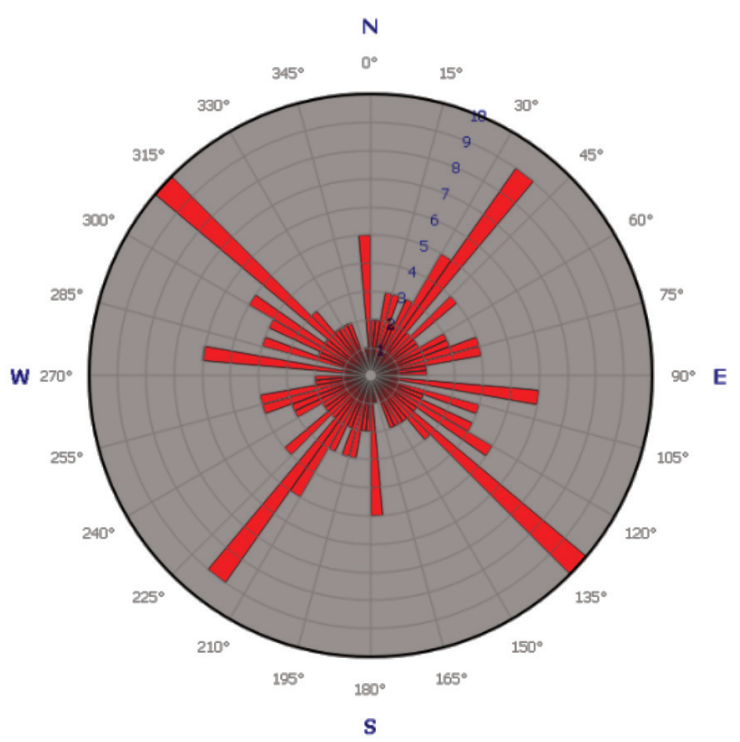

RAJAH 3. Arah utama lineamen rantau 
juga selari dengan zon sesar Kuala Lumpur dan zon sesar Bukit Tinggi (Tjia \& Zaiton 1985, Tjia 1989, Zaiton Harun 1992). Zon sesar rantau ini dipercayai mempengaruhi arah ketakselanjaran di kawasan kajian yang secara langsung dapat mengawal aliran air bawah tanah.

\section{ANALISIS PARAS AIR}

Peta kontur air bawah tanah telah dihasilkan menggunakan nilai hulu hidraulik telaga di dalam kawasan Selangor (Rajah 4). Hulu hidraulik di kawasan ini berjulat daripada 25.5 hingga $60.1 \mathrm{~m}$. Arah aliran air bawah tanah (dalam keadaan statik) adalah mengarah ke utara iaitu mengikut bentuk topografi kawasan kajian. Air bawah tanah mengalir daripada kawasan berbukit di bahagian tenggara, timur dan barat ke kawasan rendah di bahagian utara dan seterusnya mengalir ke Sungai Langat dan Sungai Semenyih.

\section{UJIAN PENGEPAMAN}

Hasil ujian pengepaman di telaga pemantauan kuari IJM Sungai Buloh merekodkan bahawa nilai kekonduksian hidraulik telaga ini adalah tinggi iaitu $0.24 \mathrm{~m} /$ hari. Paras air dalam telaga ini mengambil masa yang sangat singkat iaitu selama 27 min untuk kembali kepada paras air asal. Telaga ini berada di dalam lapisan granit terluluhawa seperti pasir berlempung dan lodak. Oleh itu, dapat disimpulkan bahawa nilai kekonduksian hidraulik yang tinggi dalam telaga pemantauan ini adalah dipengaruhi oleh kadar ketelapan lapisan terluluhawa yang tinggi.

Kebanyakan telaga dalam batuan granit mencatatkan kadar luahan yang rendah dengan nilai kurang daripada 10 $\mathrm{m}^{3} /$ jam. Menurut Shirazi et al. (2015), nilai kadar luahan

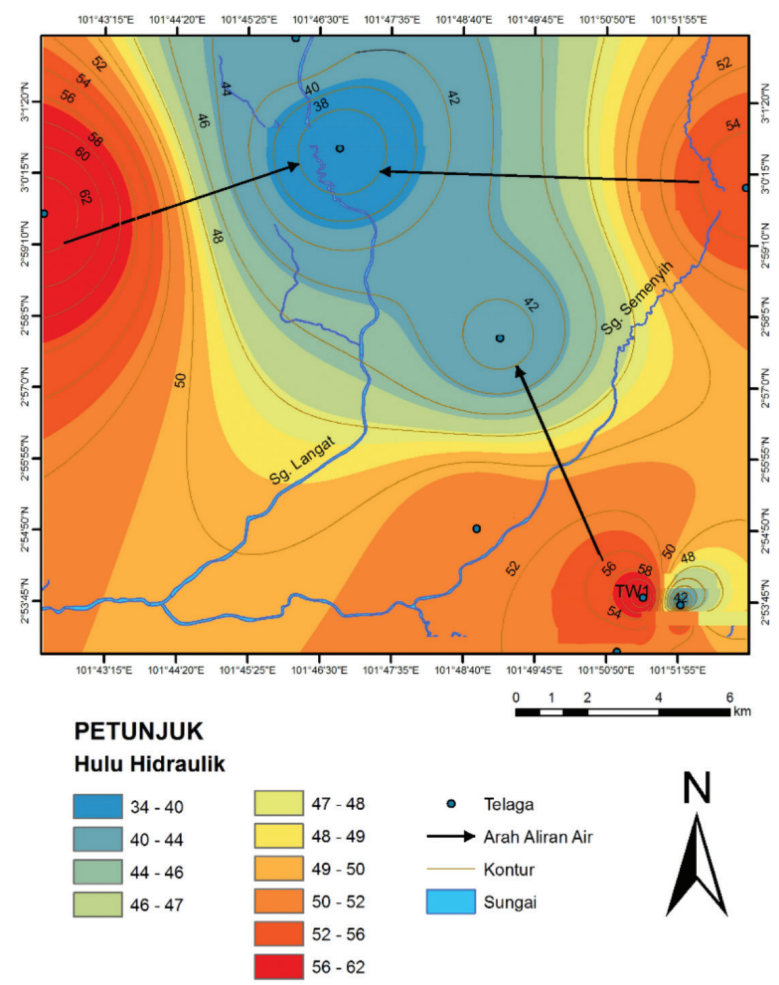

RAJAH 4. Peta kontur air bawah tanah telaga dalam batuan granit di Selangor

ini dikelaskan sebagai sederhana. Namun begitu, terdapat 4 buah telaga yang mencatatkan kadar luahan melebihi $10 \mathrm{~m}^{3} / \mathrm{jam}$ iaitu dengan kadar luahan yang paling tinggi $18.07 \mathrm{~m}^{3} /$ jam dengan kedalaman telaga sedalam $66 \mathrm{~m}$. Jadual 1 menunjukkan nilai keterusan, T dan kekonduksian

JADUAL 1. Rumusan nilai keterusan, $\mathrm{T}$ ( $\mathrm{m}^{2} /$ hari) dan kekonduksian hidraulik, $\mathrm{K}$ (m/hari) berdasarkan setiap kaedah

\begin{tabular}{|c|c|c|c|c|c|c|c|c|c|}
\hline \multirow{3}{*}{ Telaga } & \multicolumn{4}{|c|}{ Ujian surutan bertingkat } & \multirow{2}{*}{\multicolumn{2}{|c|}{$\begin{array}{c}\text { Ujian luahan tetap } \\
\text { Cooper-Jacob }\end{array}$}} & \multirow{2}{*}{\multicolumn{2}{|c|}{$\begin{array}{c}\text { Ujian pemulihan } \\
\text { Theis }\end{array}$}} & \multirow{3}{*}{ Jenis akuifer } \\
\hline & \multicolumn{2}{|c|}{ Hantush-Bierschenk } & \multicolumn{2}{|c|}{ Eden-Hazel } & & & & & \\
\hline & $\mathrm{T}$ & $\mathrm{K}$ & $\mathrm{T}$ & K & $\mathrm{T}$ & $\mathrm{K}$ & $\mathrm{T}$ & $\mathrm{K}$ & \\
\hline \multirow{8}{*}{ Telaga di Beranang } & 10.65 & 0.37 & 19.46 & 0.67 & 14.76 & 0.51 & 1.02 & 0.035 & Separa terkekang \\
\hline & 10.65 & 0.44 & 9.79 & 0.41 & 6.75 & 0.28 & 5.05 & 0.21 & Terkekang \\
\hline & 2.32 & 0.077 & 7.54 & 0.25 & 8.39 & 0.28 & 2.34 & 0.078 & Terkekang \\
\hline & 17.66 & 0.82 & 17.42 & 0.81 & 4.11 & 0.19 & 2.26 & 0.11 & Terkekang \\
\hline & 12.82 & 0.25 & 49.26 & 0.96 & 36.14 & 0.7 & 27.95 & 0.54 & Terkekang \\
\hline & - & - & - & - & 2.85 & 0.14 & 1.07 & 0.054 & Tidak Terkekang \\
\hline & 15.668 & 0.89 & 10.24 & 0.58 & 3.66 & 0.21 & 3.19 & 0.18 & Separa Terkekang \\
\hline & 4.34 & 0.055 & 4.33 & 0.055 & 9.09 & 0.11 & 1 & 0.013 & Separa Terkekang \\
\hline \multirow{3}{*}{ Telaga di Semenyih } & - & - & - & - & 9.15 & 4.58 & 6.06 & 3.03 & Terkekang \\
\hline & - & - & - & - & 6.46 & 0.22 & - & - & Terkekang \\
\hline & 6.52 & 0.13 & 6.81 & 0.085 & 5.45 & 0.11 & 2.86 & 0.057 & Tidak Terkekang \\
\hline Telaga di Cheras & 31.2 & 1.3 & 31.83 & 1.33 & 14.71 & 0.61 & 12.05 & 0.5 & Terkekang \\
\hline Telaga di Seri Kembangan & - & - & - & - & - & - & 4.66 & 0.93 & - \\
\hline \multirow{2}{*}{ Telaga di Kajang } & 11.41 & 0.28 & 9.05 & 0.22 & 2.62 & 0.064 & 1.91 & 0.047 & Terkekang \\
\hline & 210.34 & 1.98 & 15.86 & 0.15 & 21.95 & 0.21 & 13.5 & 0.13 & Terkekang \\
\hline
\end{tabular}


hidraulik, $\mathrm{K}$ hasil analisis data ujian pengepaman bagi akuifer batuan granit di Selangor. Nilai yang diperoleh daripada kaedah Cooper-Jacob adalah lebih meyakinkan kerana data ini adalah bebas daripada kesan simpanan telaga. Nilai $\mathrm{T}$ yang diperoleh berjulat daripada 2.6 hingga $36.1 \mathrm{~m}^{2} /$ hari iaitu dikelaskan sebagai rendah hingga sederhana (Krasny 1993). Nilai kekonduksian hidraulik daripada kaedah ini pula adalah 0.06 hingga $4.6 \mathrm{~m} /$ hari. Selain daripada itu, didapati akuifer di kawasan kajian boleh berubah menjadi separa terkekang apabila dipam (Rajah 5).

\section{ANALISIS KIMIA AIR BAWAH TANAH}

Berdasarkan hasil analisis data kimia (Jadual 2), sampel air bawah tanah di kawasan kajian secara umumnya dicirikan oleh pH asid lemah hingga neutral (5.42 hingga 8.4) yang dapat dikaitkan dengan pengaruh bahan organik di dalam lapisan batuan terluluhawa di bahagian atas. Selain itu, sampel air bawah tanah ini secara umumnya juga kurang mengalami permineralan dengan nilai kekonduksian berjulat daripada 36 hingga $584 \mu \mathrm{S} / \mathrm{cm}$ dan nilai jumlah pepejal terlarut kurang daripada $370 \mathrm{mg} / \mathrm{L}$. Rajah 6 menunjukkan korelasi yang baik antara nilai kekonduksian dan nilai jumlah pepejal terlarut bagi sampel air di kawasan kajian. Menurut Kamtchueng et al. (2016), nilai-nilai ini menunjukkan keadaan air bawah tanah yang secara relatifnya adalah muda serta mempunyai tindakbalas kimia yang terhad dengan batuan akuifer dominan silika di kawasan kajian. Selain itu, ia menggambarkan kepelbagaian proses hidrokimia yang berlaku di dalam air bawah tanah di kawasan Selangor ini.

Secara keseluruhannya, purata kepekatan ion major bagi kation adalah dalam turutan berikut iaitu kalsium $>$ sodium $>$ kalium $>$ magnesium manakala turutan bagi anion adalah bikarbonat $>$ klorida $>$ sulfat $>$ nitrat. Kalsium dan sodium direkodkan pada kepekatan yang lebih tinggi di dalam air bawah tanah kawasan kajian berbanding kalium dan magnesium. Ini berkemungkinan akibat hasil perlarutan dan luluhawa mineral di dalam batuan seperti feldspar yang mengandungi kalsium. Dalam kalangan unsur surih, ferum dan mangan adalah unsur yang lazim hasil daripada luluhawa batuan pembawa biotit dan hornblend dengan kepekatan kedua-dua unsur ini didapati berkait antara satu sama lain.

Oleh kerana telaga abstraksi air bawah tanah ini terletak di kawasan bandar atau industri, kehadiran unsur ion major seperti $\mathrm{SO}_{4}, \mathrm{NO}_{3}, \mathrm{Cl}$ dan juga $\mathrm{K}$ juga boleh dikaitkan dengan berlakunya pencemaran yang dikaitkan dengan kebocoran tangki septik atau sisa kumbahan dalam air bawah tanah (Eiswirth \& Hötzl 1997; Ford \& Tellam 1994; Grischek et al. 1996). Rajah 7 menunjukkan sampel air telaga yang mempunyai nilai $\mathrm{SO}_{4}, \mathrm{NO}_{3}, \mathrm{Cl}$ - dan juga $\mathrm{K}$ yang lebih tinggi berbanding sampel lain.

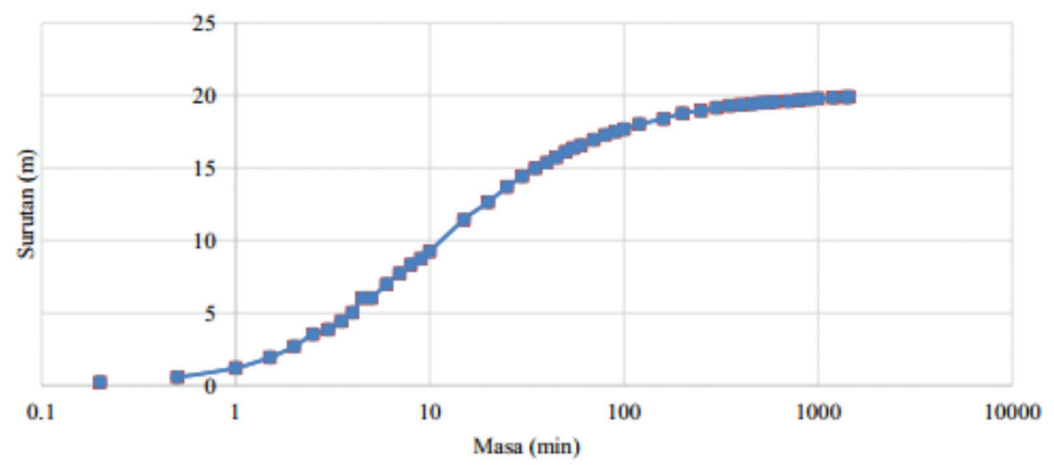

RAJAH 5. Lengkung surutan melawan log masa yang menunjukkan akuifer separa terkekang

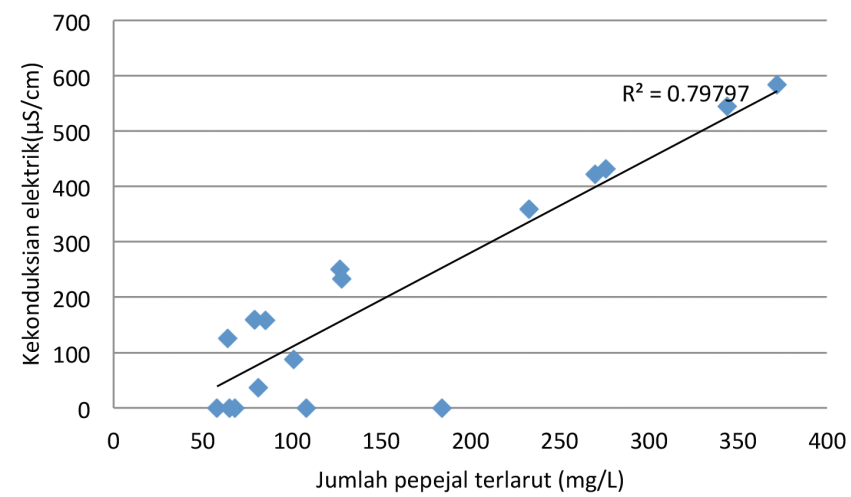

RAJAH 6. Graf kekonduksian melawan jumlah pepejal terlarut (TDS) 


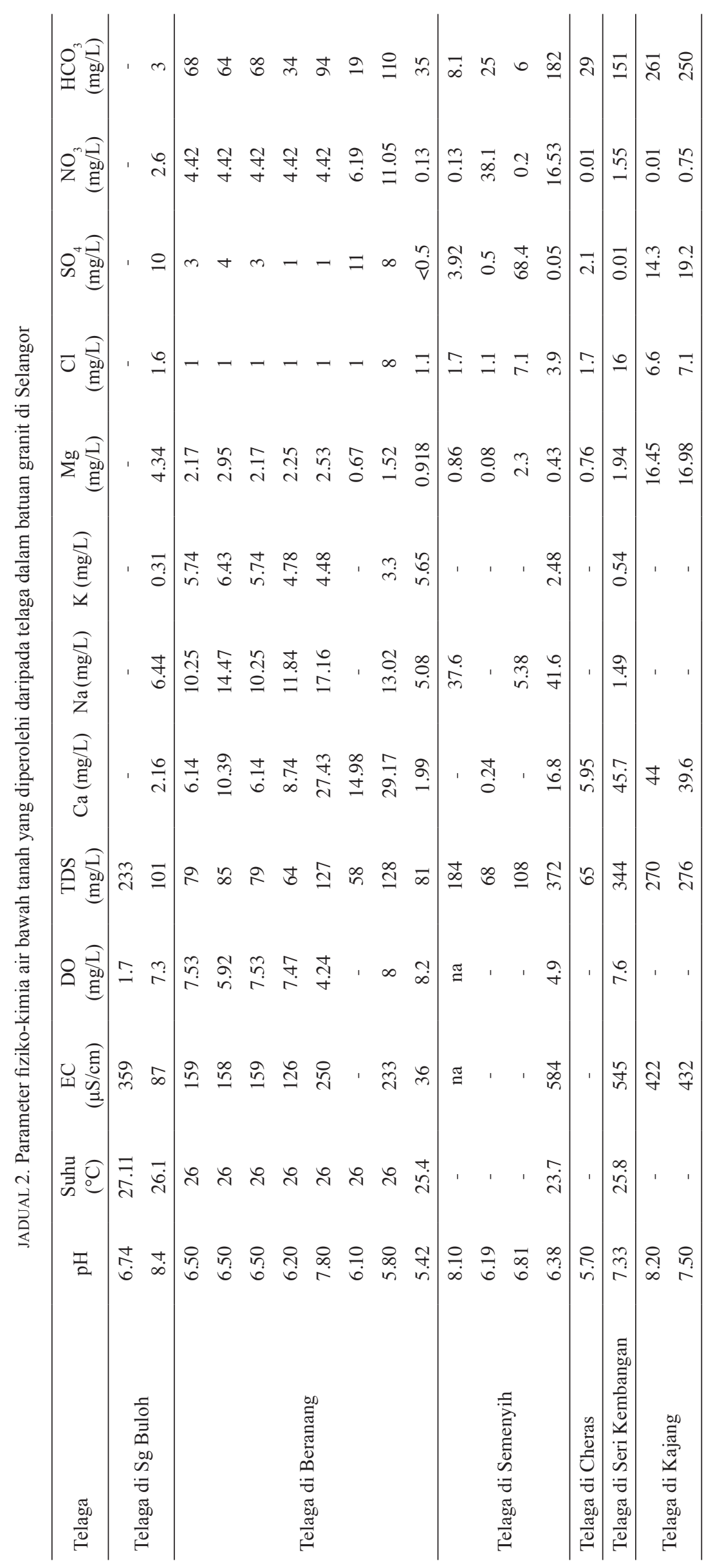



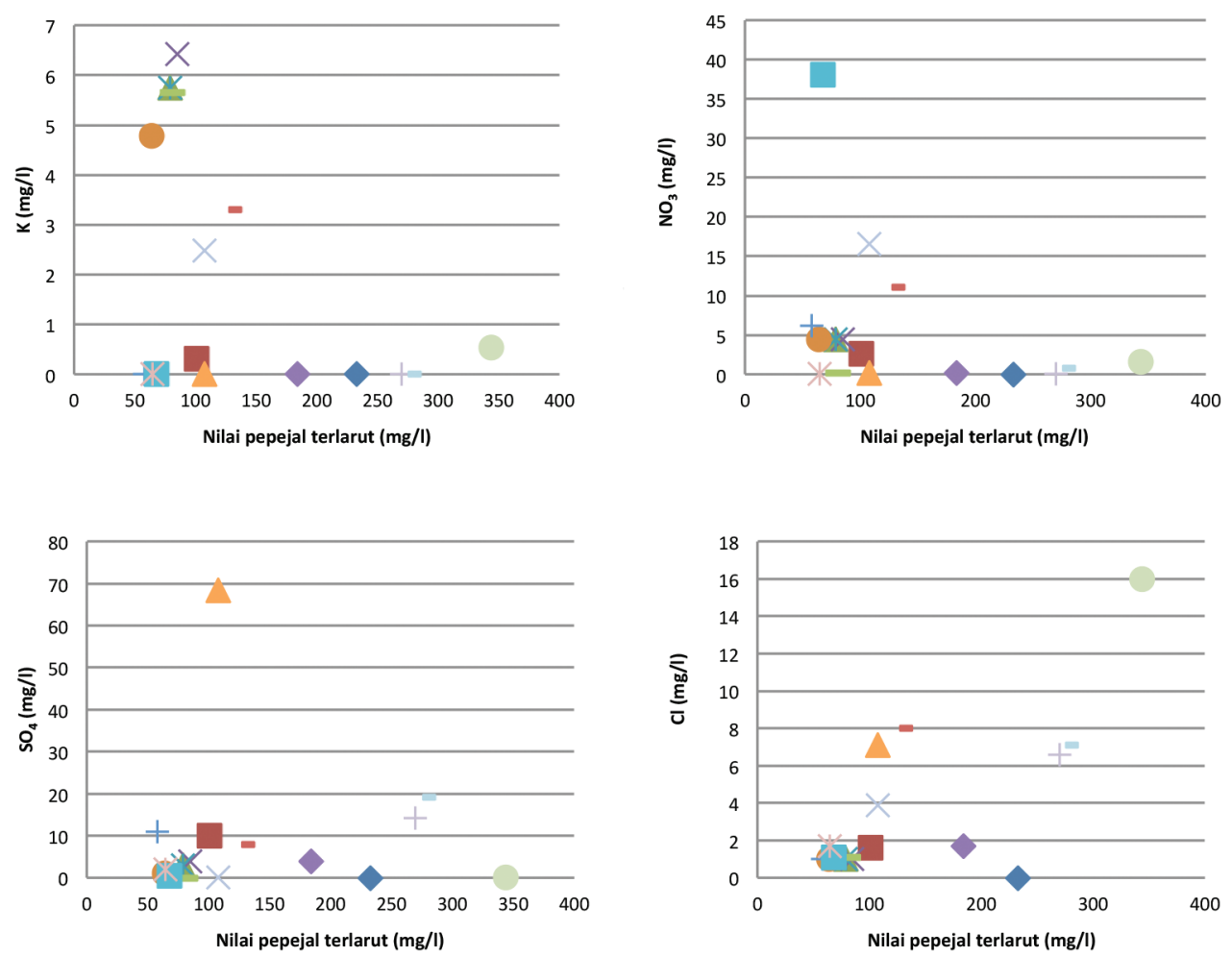

RAJAH 7. Terdapat sampel-sampel air telaga yang mempunyai nilai ion $\mathrm{SO}_{4}, \mathrm{NO}_{3}, \mathrm{Cl}$ dan juga $\mathrm{K}$ yang lebih tinggi berbanding sampel air telaga lain. Sampel air telaga ini berkemungkinan dicemari dengan sisa kumbahan

\section{KESIMPULAN}

Secara keseluruhannya, akuifer telaga dalam batuan granit di Selangor adalah dalam keadaan terkekang (dalam keadaan statik) dan berubah menjadi separa terkekang apabila telaga dipam. Nilai keterusan yang diperoleh daripada analisis ujian pengepaman adalah berjulat daripada 2.6 hingga $36.1 \mathrm{~m}^{2} /$ hari yang dikelaskan sebagai rendah hingga sederhana. Nilai kekonduksian hidraulik pula adalah 0.06 hingga $4.6 \mathrm{~m} /$ hari. Kehadiran retakan di dalam batuan granit memainkan peranan penting dalam keupayaan akuifer. Kedudukan telaga abstraksi yang terletak di kawasan bandar atau industri menyebabkan sumber air bawah tanah berpotensi untuk tercemar. Justeru, pemahaman tentang sifat akuifer akan banyak membantu dalam aktiviti pemantauan pada masa akan datang.

\section{PENGHARGAAN}

Setinggi-tinggi penghargaan dan terima kasih kepada Jabatan Mineral dan Geosains Selangor (JMG) yang telah membekalkan data telaga di Selangor serta pihak kuari IJM Sungai Buloh yang membenarkan kerja lapangan dijalankan di kawasan kuari di samping turut berkongsi data yang ada.

\section{RUJUKAN}

Brassington, R. 1998. Field Hydrogeology. Ed. 2. Chichester: John Wiley \& Sons.
Brown,E.T. 1981.ISRM Suggested Method,Rock Characterization Testing and Monitoring. New York: Pergamon Press Ltd.

Cobbing, E.J., Mallick, D.I.J., Pitfield, P.E.J. \& Teoh, L.H. \& 1986. The granites of the South-East Asian tin belt. Journal of Geological Society 143: 537-550.

Eiswirth, M. \& Hötzl, H. 1997. The impact of leaking sewers on urban groundwater. Groundwater in the Urban Environment 1: $399-404$

Ford, M. \& Tellam, J.H. 1994. Source, type and extent of inorganic contamination within the Birmingham urban aquifer system, UK. Journal of Hydrology 156(1): 101-135.

Grischek, T., Nestler, W., Piechniczek, D. \& Fischer, T. 1996. Urban groundwater in Dresden, Germany. Hydrogeology Journal 4(1): 48-63.

Henriksen, H. \& Braathen,A. 2006. Effects of fracture lineaments and in-situ rock stresses on groundwater flow in hard rocks: A case study from Sunnfjord, western Norway. Hydrogeology Journal 14(4): 444-461.

Kamtchueng, B.T., Fantong, W.Y., Wirmvem, M.J., Tiodjio, R.F. \& Takounjou, A.F. 2016. Hydrogeochemistry and quality of surface water and groundwater in the vicinity of Lake Monoun, West Cameroon: Approach from multivariate statistical analysis and stable isotopic characterization. Environ. Monit. Assess. 188: 524.

Krasny, J. 1993. Classification of transmissivity magnitude and variation. Ground Water 31(2): 230-236.

Saim Suratman. 1991. Hidrogeologi kawasan Lembah Klang dengan penekanan terhadap akuifer batu kapur. Tesis Sarjana, Universiti Kebangsaan Malaysia (tidak diterbitkan).

Shirazi, S.M., Adham, M.D., Zardari, N.H., Ismail, Z., Imran, H.M. \& Mangrio, M.A. 2015. Groundwater quality and 
hydrogeological characteristics of Malacca state in Malaysia. Journal of Water and Land Development 24(1-3):11-19.

Singhal, B.B.S. \& Gupta, R.P. 1999. Applied Hydrogeology of Fractured Rocks. Dodrecht, Netherlands: Kluwer Academic Publishers.

Tjia, H.D. \& Zaiton Harun. 1985. Regional structures of Peninsular Malaysia. Sains Malaysiana 14(1): 95-107.

Tjia, H.D. 1989. Major faults of Peninsular Malaysia on remotelysensed images. Sains Malaysiana 18(1): 101-114.

Zaiton Harun. 1992. Anatomi sesar-sesar utama Semenanjung Malaysia. Tesis Dr. Fal, Universiti Kebangsaan Malaysia. hlm. 263 (tidak diterbitkan).
Program Geologi, Pusat Sains Sekitaran dan Sumber Alam Fakulti Sains dan Teknologi

Universiti Kebangsaan Malaysia

43600 UKM Bangi, Selangor Darul Ehsan

Malaysia

*Pengarang untuk surat-menyurat; email: finalan@ukm.edu.my

Diserahkan: 26 Oktober 2016

Diterima: 30 Jun 2017 